\title{
SCHOOL AND EMPLOYMENT RECORDS OF TEENAGE GIRLS WITH VENEREAL DISEASE IN MANCHESTER*
}

\author{
BY \\ S. M. LAIRD \\ Director, St. Luke's Clinic and V.D. Department, Royal Infirmary, Manchester
}

\begin{abstract}
Venereal disease in teenage patients, and especially in teenage girls, has attracted attention and comment in recent years throughout the world. The numbers of teenage girls attending the V.D. clinics of the City of Manchester have increased three-fold since 1955 (Table I), but the absolute numbers, 113 cases of gonorrhoea in 1962, out of a total population of two and half millions, suggests that this problem is less alarming in Manchester than in large cities in many other countries.
\end{abstract}

\section{TABLE I}

NUMBER OF FEMALES AGED 14 TO 19 YEARS WITH GONORRHOEA SEEN IN V.D. CLINICS OF THE CITY OF MANCHESTER, 1951-1962

\begin{tabular}{|c|c|c|c|c|c|c|}
\hline Year & .. & 1951 & 1955 & 1959 & 1961 & 1962 \\
\hline No. of Cases & $\ldots$ & 41 & 44 & 101 & 126 & 113 \\
\hline
\end{tabular}

Talking with these young patients and the retrospective perusal of their case records for another study (Laird, 1962) suggested that many of these girls had a poor educational background and that they tended to drift from one unskilled job to another. Other unfavourable social influences were also noted, and a planned study of these factors commenced in August, 1962, at St. Luke's Clinic, Manchester. A standard questionnaire was completed by our social worker or nursing sister for all teenage girls seen by me. This present paper reports only the information recorded about the educational attainments and employment records in the first sixty consecutive teenage patients born in the United Kingdom, four girls being excluded from the present analysis because they were born and educated outside the U.K. Of these sixty girls, $31(51 \cdot 8$ per cent.) had gonorrhoea, 22 (36.6 per cent.) had other conditions requiring treatment, and in seven $(11 \cdot 6$

* Short paper read at the M.S.S.V.D. meeting in Copenhagen on June 6, 1963. per cent.) nothing abnormal was found; none had syphilis. The full study continues and the results will be reported later. It is emphasized that the data represent the patients' unconfirmed statements, but there seems no good reason for them to give untruthful answers to simple questions regarding performance in school examinations and their work record, both of which, so far as they knew, might be subject to confirmation.

\section{Educational Records}

During more than the past decade the state educational authorities in England have attempted, by examination at the age of about 11 years, to select those children considered likely to benefit from education in a grammar school with the possibility of proceeding to the university. This latter possibility depends on their reaching the required academic standard in the further examinations for the General Certificate of Education (G.C.E.) at Ordinary and Advanced levels. Those not selected for the grammar schools go to the secondary modern schools where a more technical education with an introduction to manual skills is provided. This examination for 11-year-olds, known as the "11plus" examination, causes concern to children and parents alike and has many critics.

Of the sixty girls included in the present study, 33 (55 per cent.) claimed to have "passed" the 11-plus examination. The percentage of children passing the examination varies from one area to another but the estimated average for the whole country is about 30 per cent.; in Manchester 29 per cent. passed in 1962. This group of girls, if their statements are true, thus achieved more than the average performance in the "11-plus" examination.

The examination for the General Certificate of Education (G.C.E.) at Ordinary level is taken at about 16 years of age. The number of subjects 
attempted largely depends on each child's performance in the "mock" tests arranged by the school about 3 months before the national examination, and may vary from one or two up to ten. In the 1962 examination Manchester pupils averaged $3 \cdot 48$ subject passes.

Of the 33 teenage patients who claimed to have passed the 11-plus test, seventeen stated that they had obtained sixty subject passes in the G.C.E. at Ordinary level (average $3 \cdot 5$ subject passes). However, these 33 patients included four who were college students when they attended the clinic and these four alone accounted for 22 subject passes at Ordinary level. Thus the remaining 29 girls obtained only 38 subject passes, an average of only $1 \cdot 3 \mathrm{com}$ pared to the 3.48 average throughout the Manchester schools. Thus our group of teenage patients were in general well below average as judged by their performance in G.C.E. at Ordinary level.

Three ( 5 per cent.) of the teenage patients had passed G.C.E. at Advanced level and averaged 2.3 subject passes. One, who was taking an Arts degree at University, had passed in four subjects and another, an art student, in one subject only; the third, who passed in two subjects, married on leaving school and, when she attended the clinic at 18 years of age, was obtaining a divorce. In Manchester during 1962, about 10 per cent. of schoolleavers sat for the G.C.E. at Advanced level and averaged $2 \cdot 24$ subject passes. The educational performance of the sixty teenage patients, judged by the G.C.E. Advanced level, was only about half the average for Manchester.

\section{EMPLOYMENT RECORDS}

The employment status of the teenage patients at the time of their attendance at the Clinic is shown in Table II ; 10 per cent. were still students, 17 per cent. were unemployed, and 73 per cent. were working.

TABLE II

EMPLOYMENT AT TIME OF ATTENDING CLINIC

\begin{tabular}{|c|c|c|c|c|c|}
\hline \multicolumn{3}{|c|}{ Employment } & \multicolumn{2}{|c|}{ No. } & Per cent. \\
\hline $\begin{array}{l}\text { Still at School . } \\
\text { Student at College }\end{array}$ & $\begin{array}{l}\cdots \\
\cdots\end{array}$ & $\begin{array}{l}\cdots \\
\cdots\end{array}$ & $\begin{array}{l}2 \\
4\end{array}$ & 6 & 10 \\
\hline $\begin{array}{l}\text { Unemployed } \\
\text { In Legal Care }\end{array}$ & $\begin{array}{l}\cdots \\
\cdots\end{array}$ & $\begin{array}{l}\ldots \\
\ldots\end{array}$ & $\begin{array}{l}9 \\
1\end{array}$ & 10 & 17 \\
\hline Employed & $\cdots$ & $\ldots$ & 44 & 44 & 73 \\
\hline Total ... & $\ldots$ & .. & \multicolumn{2}{|c|}{60} & 100 \\
\hline
\end{tabular}

Excluding the students, only nine ( $16 \cdot 6$ per cent.) were still in their original job, and ten $(18 \cdot 5$ per cent.) had each had five to seven jobs (Table III). The average number of jobs per girl $(4 \cdot 1)$ was twice as high in those who had not passed the 11-plus examination (Table IV). Tables III and IV show clearly that the poorer the educational record the greater is the tendency to drift from one job to another. This may be due to the unskilled and boring nature of the job or to its lack of prospects of advancement; alternatively, the fault may lie in the temperament and character of the teenager.

TABLE III

NUMBER OF JOBS HELD SINCE LEAVING SCHOOL (EXCLUDING STUDENTS), BY EDUCATIONAL RECORD

\begin{tabular}{|c|c|c|c|c|c|c|}
\hline \multicolumn{5}{|c|}{ No. of Jobs } & \multicolumn{2}{|c|}{$11+$ Examination } \\
\hline & & & & & \multirow{2}{*}{$\begin{array}{c}\text { Passed } \\
8\end{array}$} & \multirow{2}{*}{$\frac{\text { Failed }}{1}$} \\
\hline One & $\cdots$ & . & $\cdots$ & $\cdots$ & & \\
\hline Two & $\ldots$ & $\ldots$ & $\ldots$ & $\ldots$ & 7 & 3 \\
\hline Three & $\cdots$ & $\cdots$ & $\cdots$ & $\cdots$ & 10 & 6 \\
\hline Four & $\ldots$ & $\cdots$ & $\cdots$ & $\ldots$ & 2 & 4 \\
\hline Five & $\cdots$ & $\cdots$ & . & $\ldots$ & - & 6 \\
\hline$\overline{\operatorname{Six}}$ & . & $\cdots$ & . & $\ldots$ & - & 1 \\
\hline Seven & $\ldots$ & $\ldots$ & $\ldots$ & $\ldots$ & - & 7 \\
\hline
\end{tabular}

TABLE IV

AVERAGE NUMBER OF JOBS HELD SINCE LEAVING SCHOOL (EXCLUDING STUDENTS), BY EDUCATIONAL RECORD AND AGE

\begin{tabular}{|c|c|c|c|c|c|c|}
\hline \multirow{2}{*}{\multicolumn{5}{|c|}{ Age (yrs) }} & \multicolumn{2}{|c|}{$11+$ Examination } \\
\hline & & & & & \multirow{2}{*}{$\frac{\text { Passed }}{2 \cdot 16}$} & \multirow{2}{*}{$\begin{array}{c}\text { Failed } \\
3 \cdot 86\end{array}$} \\
\hline 17 & $\ldots$ & . & . & . & & \\
\hline 18 & $\ldots$ & . & . & . & $2 \cdot 36$ & $3 \cdot 4$ \\
\hline 19 & $\cdots$ & . & $\cdots$ & . & $1 \cdot 7$ & $3 \cdot 66$ \\
\hline Total & $\ldots$ & $\ldots$ & $\ldots$ & $\ldots$ & $2 \cdot 2$ & $4 \cdot 1$ \\
\hline
\end{tabular}

The nature of the employment is summarized in Table V; typist, factory-worker, waitress, and shop assistant predominate.

TABLE V

TYPE OF EMPLOYMENT IN CURRENT AND PREVIOUS JOB

\begin{tabular}{|c|c|c|c|c|c|}
\hline \multirow{2}{*}{\multicolumn{4}{|c|}{ Employment }} & \multicolumn{2}{|c|}{ Job } \\
\hline & & & & \multirow{2}{*}{$\frac{\text { Current }}{8}$} & \multirow{2}{*}{ Previous } \\
\hline Typist/Secretary/Clerk & $\cdots$ & $\cdots$ & $\cdots$ & & \\
\hline Factory Worker & $\cdots$ & $\cdots$ & $\cdots$ & 13 & 16 \\
\hline \multicolumn{3}{|c|}{ Waitress/Barmaid/Usherette/Coffee Bar } & $\cdots$ & 11 & 4 \\
\hline \multicolumn{2}{|c|}{ Shop Assistant/Hairdresser } & $\cdots$ & $\cdots$ & 5 & 9 \\
\hline Telephonist $\ldots$ & $\cdots$ & $\cdots$ & $\cdots$ & 1 & 2 \\
\hline \multicolumn{2}{|c|}{ Children's Nurse/Nursemaid } & $\cdots$ & $\cdots$ & 2 & 2 \\
\hline Model & $\cdots$ & . & $\cdots$ & 1 & 1 \\
\hline Domestic in House .. & $\cdots$ & $\cdots$ & $\cdots$ & 3 & 3 \\
\hline
\end{tabular}




\section{Summary}

A standard questionnaire has been used to study the school and employment records of sixty teenage girls seen consecutively at a V.D. clinic in Manchester during the 8 months ending March, 1963.

55 per cent. had passed the national (11-plus) examination and, of the 33 girls who went to grammar schools, seventeen obtained sixty subject passes in the General Certificate of Education (G.C.E.) at Ordinary level. Three girls progressed further and obtained seven subject passes at the G.C.E. Advanced level. Four of these 33 girls became students after leaving school and these account for 22 subjects passed at Ordinary level and five at Advanced level. Thus the other 29 girls averaged only 1.3 subject passes at Ordinary level and 0.07 at Advanced level.

When these sixty girls attended the V.D. clinic, 10 per cent. were still students, 17 per cent. were not employed, and 73 per cent. were working. Excluding students, only nine ( 16.6 per cent.) were still in their original job, while ten ( 18.5 per cent.) had each had five to seven jobs. The average number of jobs per girl was twice as high $(4 \cdot 1)$ in those who had not passed the 11-plus examination.

It is concluded that, in Manchester, girls attending the V.D. clinic usually have a poor educational record and frequently change their employment.

\section{REFERENCE}

Laird, S. M. (1962). Brit. J. vener. Dis., 38, 134.

\section{L'histoire des études et de l'emploi des jeunes femmes} atteintes de maladie vénérienne à Manchester

\section{RÉSUMÉ}

On a examiné grâce à un questionnaire l'histoire de 60 jeunes femmes âgées de 13 à 19 ans qui se présenterènt à une clinique antivénérienne à Manchester d'août 1962 à mars 1963.

33 de ces jeunes filles furent élevées au lycée et 17 réussirent en 60 sujets à l'examen d'éducation générale. Trois de ces dernières réussirent de plus en 7 sujets à l'examen plus avançé, et quatre sont entrées à l'université.

Quand elles vinrent à la clinique $10 \%$ étaient encore à l'école ou au collège, $17 \%$ ne faisaient rien, et $73 \%$ travaillaient. Les écolières et les étudiantes à part, il n'y en avait que $9(16,6 \%)$ qui avaient encore le même emploi, et 10 $(18,5 \%)$ avaient pris de 5 à 7 emplois différents.

Celles qui ne furent pas élevées au lycée avaient changé leur emploi deux fois plus souvent (nombre moyen de postes $=4,1$ ).

L'auteur constate qu'à Manchester les jeunes filles atteintes de maladie vénérienne ont ordinairement une éducation médiocre et changent très souvent leur emploi. 